\title{
Rediscovery of Chiococca insularis (Ridley) C.M.Taylor \& M.R.V.Barbosa (Rubiaceae), a species presumed extinct, on the island of Fernando de Noronha, Pernambuco, Brazil
}

\author{
Maurício Figueira ${ }^{1}$, Bianca Schindler ${ }^{1}$, Jomar G. Jardim²,3, Maria Regina de V. Barbosa ${ }^{4}$ \\ 1 Serviço Florestal Brasileiro, Herbário CEN, Embrapa Recursos Genéticos e Biotecnologia (CENARGEN), Brasília, Distrito Federal, 70770-917, \\ Brazil. 2 Universidade Federal do Sul da Bahia, Centro de Formação em Ciências Agroflorestais, Rod. BR415 s.n., Ferradas, Itabuna, Bahia, 45613- \\ 204, Brazil. 3 Herbário CEPEC, Centro de Pesquisas do Cacau (CEPLAC), Km 29 Rod. Ilhéus/Itabuna, Bahia, 45604-811 Brazil. 4 Universidade \\ Federal da Paraíba, Centro de Ciências Exatas e da Natureza, Departamento de Sistemática e Ecologia, Caixa Postal 5065, Cidade Universitária, \\ João Pessoa, Paraíba, 58051-970, Brazil. \\ Corresponding author: Maria Regina de V. Barbosa, mregina@dse.ufpb.br
}

\begin{abstract}
Chiococca insularis (Ridley) C.M.Taylor \& M.R.V.Barbosa (Rubiaceae) was described by Henry Nicholas Ridley in 1890, based on a collection he made on the island of Fernando de Noronha (Pernambuco, Brazil) in 1887. Since then, this species had not been collected again and has been treated as probably extinct. After 130 years, we discovered two new populations in the southwestern portion of the island, and the conservation status of the species is reassessed. A full description of the species, with previously unseen or unmeasured characters, habitat information and photographs of the plant and environment are provided.
\end{abstract}

\section{Keywords}

Chiococceae, Cinchonoideae, conservation status, endemism, IUCN Red List, threatened species

Academic editor: André Scatigna | Received 11 July 2020 | Accepted 13 October 2020 | Published 30 October 2020

Citation: Figueira M, Schindler B, Jardim JG, Barbosa MRV (2020) Rediscovery of Chiococca insularis (Ridley) C.M.Taylor \& M.R.V. Barbosa (Rubiaceae), a species presumed extinct, on the island of Fernando de Noronha, Pernambuco, Brazil. Check List 16 (5): 1407-1413. https://doi.org/ $10.15560 / 16.5 .1407$

\section{Introduction}

Rubiaceae are the fourth richest angiosperm family worldwide, with more than 600 genera and ca 13,000 species, and with $38 \%$ of them occurring in the Neotropics (Davis et al. 2009; Delprete and Jardim 2012). According to Davis et al. (2009), northern and southeastern Brazil are among the 20 richest regions in the world for Rubiaceae. More than 120 genera and ca 1,400 species occur in the country, with $51 \%$ of them endemic (Flora do Brasil 2020).
Chiococca P.Browne (1756) comprises ca 25 Neotropical species of vines, shrubs, and small trees, which are distributed from southeastern North America to northern Argentina, with diversity centers in Mexico, Central America, and the Caribbean region (Jardim et al. 2015; Lorence et al. 2018; Paudyal et al. 2018). Barbosa (2019) reported four species of Chiococca in the Brazilian flora. However, according to Paudyal et al. (2018), Chiococca plowmannii Delprete (2004), which 
is endemic to northeastern coastal Brazil, belongs to Salzmannia DC. (Candolle 1830). Therefore, the currently recognized species of Chiococca from Brazil are C. alba (L.) Hitchc., C. insularis (Ridley) C.M.Taylor \& M.R.V.Barbosa, and C. nitida Benth.

Chiococca insularis is known only from the island of Fernando de Noronha, an oceanic island which is part of the Brazilian state of Pernambuco, and was originally described as Palicourea insularis Ridley (1890), based on Ridley's collection from Fernando de Noronha main island between August 14 and September 24, 1887. He reported the presence of only a few individuals in a single location, the Sapata forests. Since then, C. insularis has been known only from its type collection, despite an intensive floristic survey carried out by Freitas (2007). Currently it is categorized as Critically Endangered and probably extinct (Zappi et al. 2013).

After 130 years, during fieldwork on Fernando de Noronha (the main island of the Fernando de Noronha Archipelago), we found two new populations of $C$. insularis.

\section{Methods}

The island of Fernando de Noronha has an area of 18.4 $\mathrm{km}^{2}$ and is in the equatorial south Atlantic Ocean, 350 $\mathrm{km}$ east-northeast of Natal (Rio Grande do Norte), and $545 \mathrm{~km}$ northeast of Recife (Pernambuco) (Castro 2010). The climate is warm tropical, with annual mean temperature of $26.5^{\circ} \mathrm{C}$ and a range of $4{ }^{\circ} \mathrm{C}$. The island has two well-defined seasons: a rainy season from March to July, and a dry season from August to February (Teixeira et al. 2003). The average annual rainfall is $1,418 \mathrm{~mm}$, with a water deficit from August to February (Embrapa 2003). The rainfall, however, can vary significantly from yearto-year and can be more than 2,000 $\mathrm{mm}$ or less than 500 $\mathrm{mm}$ in some years (Teixeira et al. 2003). The archipelago has no perennial water source, but every year, as in other semi-arid regions, heavy and torrential rains during the rainy season abruptly fill the rivers and creeks, which dry out during the dry season (Ridley 1890; Machado et al. 2013).

While carrying out the Brazilian National Forest Inventory Project (Inventário Florestal Nacional [IFN] in Portuguese) in the state of Pernambuco, a series of plots were allocated on island of Fernando de Noronha. During fieldwork carried out in July 2018, a population of Chiococca insularis $\left(03^{\circ} 52^{\prime} 12^{\prime \prime} \mathrm{S}, 032^{\circ} 27^{\prime} 22^{\prime \prime} \mathrm{W}\right.$; Fig. 1A, population 1) was found and a specimen with immature fruits was collected. Another population (0352'26"S, $032^{\circ} 26^{\prime} 54^{\prime \prime} \mathrm{W}$; Fig. 1A, population 2) had already been found in September 2016 by one of us, and at that time, the population was recorded only with photos (Fig. 1), as there was no collecting permit.

We identified our collected samples by comparisons with the type specimen deposited at BM (Natural History Museum 2020), study of the taxonomic literature (Ridley 1890; Jardim et al. 2015), and consultation of online databases (Reflora 2020; INCT-Herbário Virtual 2020). We deposited our collected material in CEN and JPB (acronyms according to Thiers 2019). A full description of the species was prepared, with previously unseen or unmeasured characters included, based on the new samples and the image of the type specimen, calibrated for measurements via the FIJI program (Schindelin et al. 2012).

We evaluated the extinction risk according to the IUCN criteria and guidelines (IUCN 2012, 2019). Area of occupancy (AOO) was calculated using GeoCAT (Geospatial Conservation Assessment Tool, Bachman et al. 2011) and cell width of $0.2 \mathrm{~km}$, due to the small size of the island. Extent of occurrence (EOO) was not estimated, as it does not exceed the size of the island, and the two populations are restricted to a very small and more conserved area in the island's southwest portion.

\section{Results}

Chiococca insularis (Ridley) C.M.Taylor \& M.R.V. Barbosa, Phytotaxa 202 (1): 18. 2015. Palicourea insularis Ridley, J. Linn. Soc., Bot. 27: 41. 1890. Erithalis insularis (Ridley) Zappi \& T.S.Nunes, Kew Bull. 55: 655. 2000.

Type. BRAZIL. Pernambuco, Fernando de Noronha, main island; 26 Aug. 1887; fl and fr; Ridley, Lea \& Ramage 86 (Lectotype, designated by Zappi and Nunes 2000: BM (BM000949953) photo!; isolectotypes: B destroyed, $\mathrm{B}$ as photo $\mathrm{F}$ neg. \#599 at F (V0069990F), MO-1695030 and NY, GH 00094899 web!, K 000016495 web!, K 000016496 web!).

Figures 2, 3

Material examined. BRAZIL. Pernambuco, Fernando de Noronha, main island; $03^{\circ} 52^{\prime} 12^{\prime \prime} \mathrm{S}, 032^{\circ} 27^{\prime} 22^{\prime \prime} \mathrm{W}$, alt. 140 m, 20 Jul. 2018, fr, Figueira \& Schindler 811 (CEN 115006, JPB65084).

Photographic record. BRAZIL. Pernambuco, Fernando de Noronha, main island; $03^{\circ} 52^{\prime} 26^{\prime \prime} \mathrm{S}, 032^{\circ} 26^{\prime} 54^{\prime \prime} \mathrm{W}$, alt. 15 m, 13 Sep. 2016, Jomar G. Jardim.

Distribution, habitat, and phenology. Chiococca insularis is endemic to forests and open scrub vegetation near the seashore on the main island of the Fernando de Noronha Archipelago. It was found with flowers and fruits from June to September. The reproductive period is probably determined by the rainy season, which usually ends in July.

Recommended conservation status. Critically Endangered, B2a, b(i, ii, iii). Chiococca insularis is endemic to Fernando de Noronha, with only two known populations within the Parque Nacional Marinho de Fernando de Noronha. The AOO is $0.08 \mathrm{~km}^{2}$, much less than $10 \mathrm{~km}^{2}$. In addition to the small $\mathrm{AOO}$, the island environment is threatened mainly by population increase in recent decades and losses in the quality of habitat. On the entire 

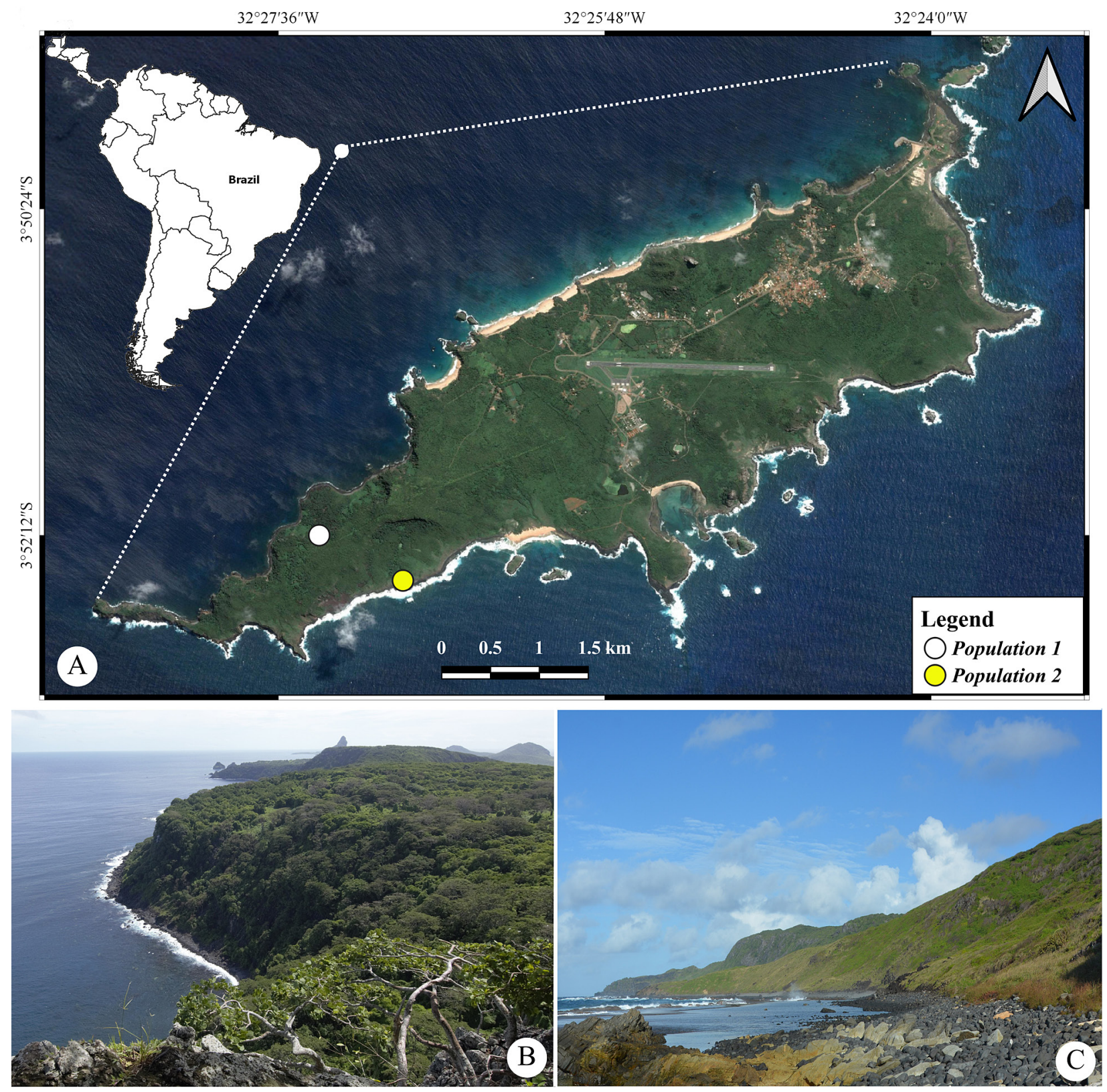

Figure 1. Island of Fernando de Noronha, Pernambuco, Brazil. A. Location of the two known populations of Chiococca insularis. B. Forest in the southwest portion of the island with population 1. C. Scrub vegetation with marine influence with population 2. Photographs by Daniel Santiago (B) and BS (C).

island, we noticed the advance of creeping vines and scandent shrubs (i.e. Jasminum fluminense Vell., Plumbago scandens L., Cissus verticillata (L.) Nicolson \& C.E.Jarvis, and Lantana camara L.) growing over trees and shrubs, and thus preventing the return of the structured condition of the natural vegetation and its ecological benefits. In addition, the island suffers from the introduction of alien tree species, such as Leucaena leucocephala (Lam.) de Wit, which grows quickly in both open spaces and the understory of the forest.

Description. Shrubs or treelets, 1-3 m tall; bark grayish; branches erect, rough, glabrous, greenish-brown or yellowish-brown when dried, densely foliate, with scarce resinous exudate at the nodes. Stipules broadly triangular, shortly united around the stem, $2-3 \times 3-5 \mathrm{~mm}$, persistent, glabrous, internally with colleters. Leaves opposite; blades elliptic to oblanceolate or obovate, (1.8) 5-7 $\times(0.6) 2-2.9 \mathrm{~cm}$, at base decurrent or cuneate, at apex acute, attenuate, cuspidate, or rounded apiculate, margin entire, slightly revolute when dried, chartaceous to coriaceous, glabrous on both surfaces, adaxially shiny; secondary veins 4-5 (6) pairs, eucamptodromous, midrib adaxially flat, abaxially slightly prominent; petioles (1) 3-7 mm long, canaliculate. Inflorescences axillary, paniculiform, lax, up to 10 -flowered; peduncle $0.5-1.3 \mathrm{~cm}$ long, glabrous; rachis $1.1-3.1 \mathrm{~cm}$ long; bracts 1.2-4.2 (5.5) $\mathrm{mm}$ long, glabrous, persistent; bracteoles, when present, $0.6-1 \mathrm{~mm}$ long. Flowers pedicellate; pedicels $9-17 \mathrm{~mm}$ long; calyx cupular, $2.5-2.7 \times 1.4-1.9 \mathrm{~mm}$, lobes 5, acute, glabrous; corolla funnelform, white, glabrous, 5.9-6.7 $\mathrm{mm}$ long (including lobes), lobes 5 , about equal to the corolla tube at anthesis, a little longer on 

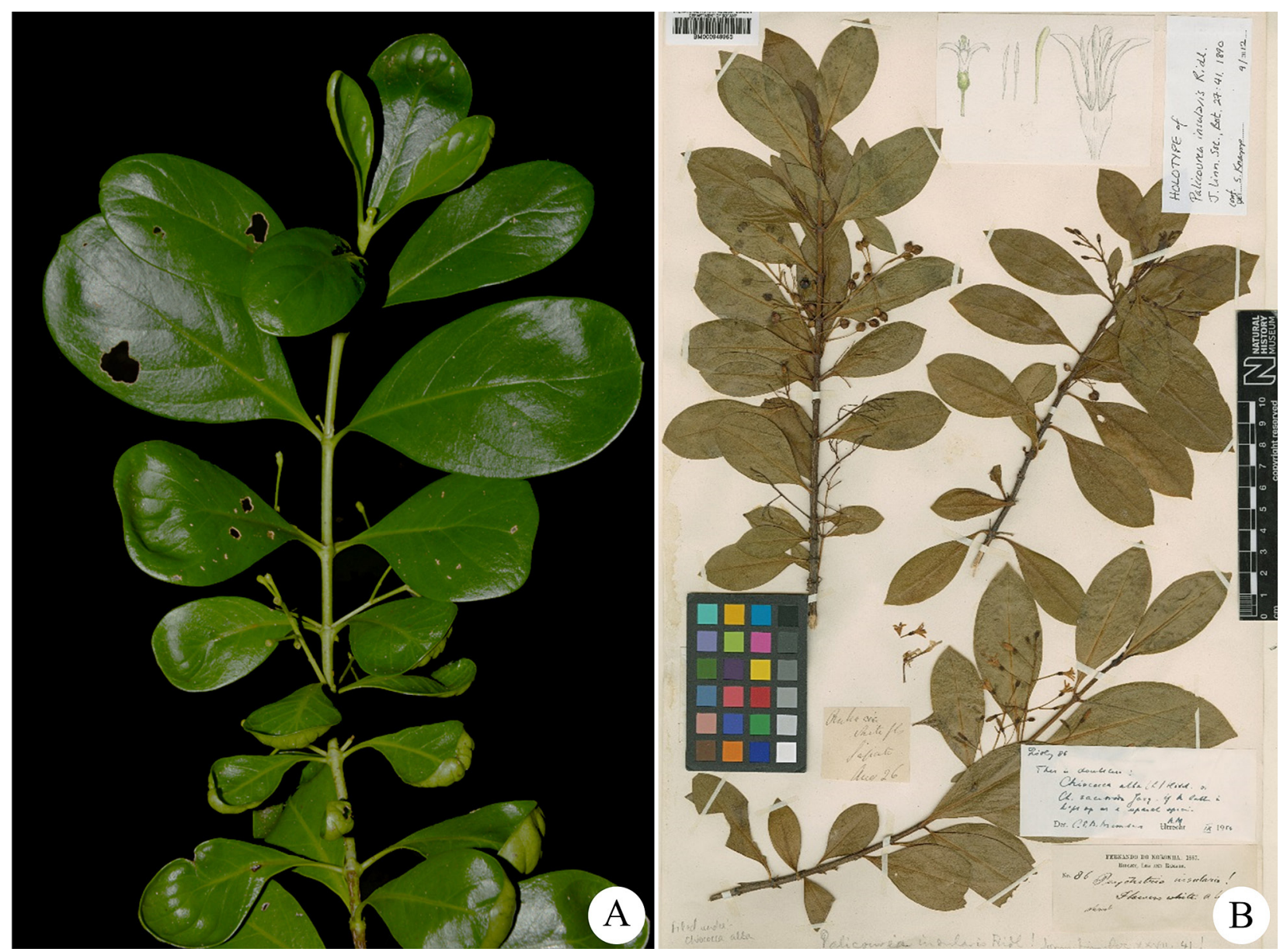

Figure 2. Chiococca insularis. A. Sample from population 1 (Figueira \& Schindler 811). B. Type (Ridley, Lea \& Ramage 86). Photographs by BS (A) and Natural History Museum (B).

older flowers, moderately reflexed; stamens 5 , anthers linear acuminate; ovary $2-5$-locular, stigma clavate, obtuse, greenish in fresh material. Fruits drupaceous, ellipsoid, 3-4.2 $\times 3.2-4.4 \mathrm{~mm}$, immature green, becoming purple and blackish when mature, $2-5$ costate at apex with persistent calyx lobes (0.8) 1.0-1.2 mm long; pyrenes 2-5.

Identification. Chiococca insularis can be distinguished from the other Brazilian species of Chiococca by its stipules not aristate; pedicels 5-17 mm long; shrub to small tree habit; and for being the only one inhabiting Fernando de Noronha.

\section{Discussion}

Zappi et al. (2013) reported that Chiococca insularis randomly colonized the island with little success, as Ridley (1890) mentioned the low number of individuals in his description. We found two populations of $C$. insularis, both in the southwest portion of the main island (Fig. 1), which is where it was originally reported. One population is in the forest and another in the scrub vegetation by the seashore. The forest environment presents rocky soils with exposed blocks of rock, flat to heavily undulating relief, with good drainage, about $140 \mathrm{~m}$ above sea level. During the dry season, the vegetation is deciduous and can be classified as a Seasonal Deciduous Forest (IBGE
2012). The forest has an irregular stratification, with two or three strata present. Tabebuia roseoalba (Ridl.) Sandwith is the dominant species in the canopy, reaching up to $20 \mathrm{~m}$ in height. In the middle layer of the forest, the most frequent species are Guapira darwinii (Hemsl.) E.C.O.Chagas \& Costa-Lima, Sideroxylon obtusifolium (Roem. \& Schult.) T.D. Penn., and Guettarda platypoda DC. The understory is richer than the other strata and is characterized by the remarkable abundance of individuals of Capparidastrum frondosum (Jacq.) Cornejo \& Iltis. Individuals of $C$. insularis are restricted to the understory.

The appearance of the scrub vegetation along the eastern coastal slope, about $15 \mathrm{~m}$ above the sea, is formed by the strong trade winds which blow westward from the sea, sculpting the woody plants and making them low, with twisted branches and rigid leaves. The relief there varies from moderate to rugged, about $15 \mathrm{~m}$ above sea level, and the soil is rocky. Poaceae, Cyperaceae, and Rubiaceae are the richest families and cover almost all the coastal slope, except on the rocky outcrops, which are often inhabited by Cereus insularis Hemsl., another endemic species on the island.

According to the Italian Amerigo Vespucci, who arrived on the island in 1503, the view was of "numerous infinite trees" (Teixeira et al. 2003). Charles Darwin, 


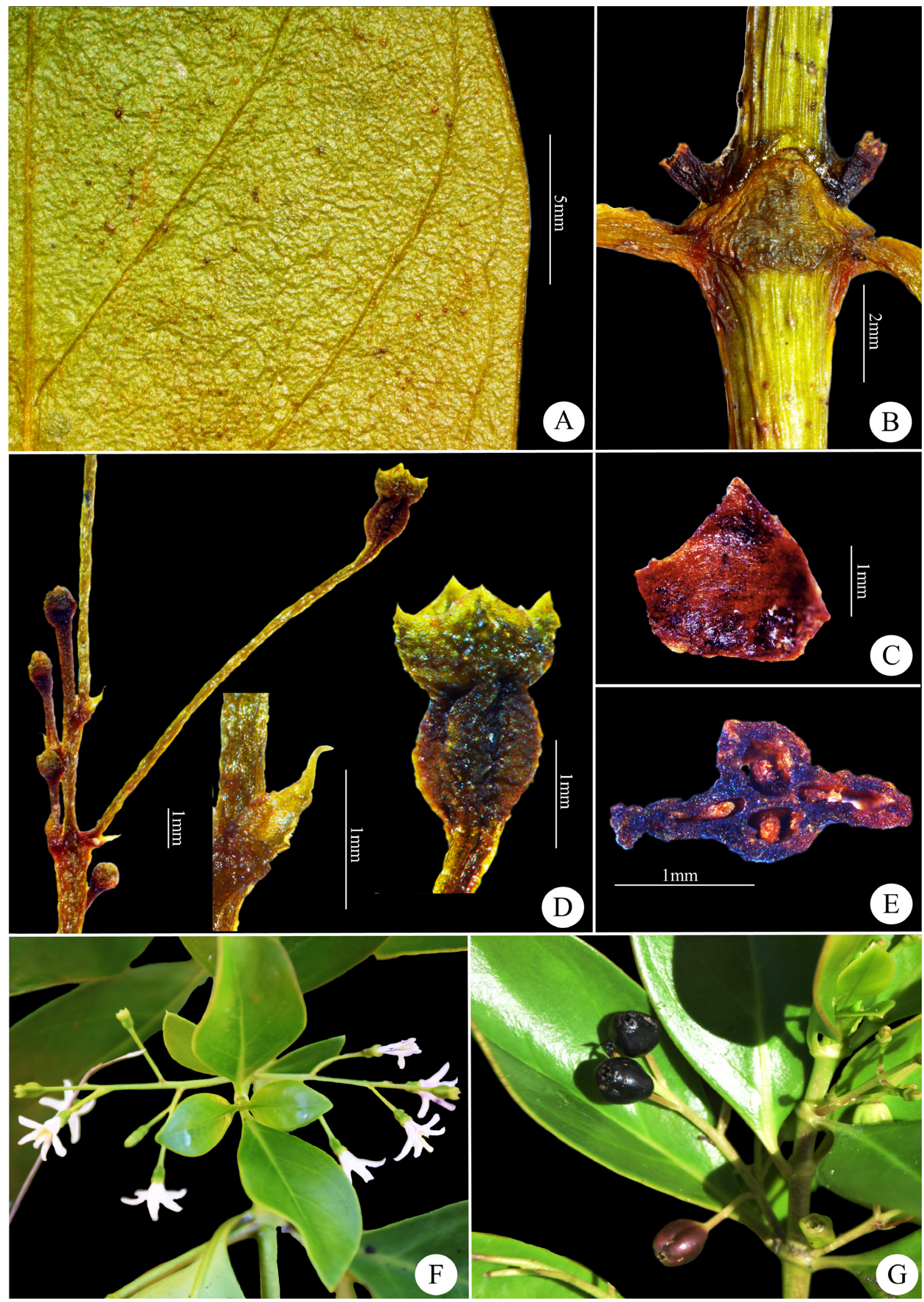

Figure 3. Chiococca insularis. A. Leaf Abaxial surface showing venation and margin. B. Interpetiolar stipule. C. Stipule internally. D. Inflorescence branchlet with bracteole and hypanthium enlarged. E. Cross-section of ovary F. Flowering branch. G. Fruits. Photographs by MF and $B S(A-E)$ and $J G J(F, G)$. 
during the HMS Beagle expedition, stayed for a few hours on the island on February 20, 1832, and stated that "the whole island is covered with forests, but due to the arid climate it has no luxuriant appearance" (Darwin 1839: 11). Almost six decades after Darwin, Ridley reported that "the western end of the island is covered with dense forest, but large trees are now not common, owing to the demand for firewood and to the strict orders for the destruction of all large trees to prevent the convicts making rafts of them on which to escape" (Ridley 1890: 5).

With these early reports, we can presume the forest physiognomy was prevalent on the main island before colonization. After its colonization in 1737 (Teixeira et al. 2003), there was a gradual increase in habitat degradation with the suppression of most of the original vegetation. The southwestern portion, where Ponta da Sapata is located, was better preserved, with the natural habitats less altered (Silva Júnior et al. 1987; Funatura 1990; Batistella 1996; Freitas 2007). This certainly contributed to the maintenance of the two populations of $C$. insularis. In both populations, but especially in the forest environment, a considerable number of fertile individuals and regenerants were found.

Therefore, we believe that $C$. insularis managed to survive in the southwest portion of the island because the site maintained adequate environmental conditions and is protected within the limits of the Parque Nacional Marinho de Fernando de Noronha. Data collection will be necessary to accurately estimate the size of populations and monitor the impact of threats.

\section{Acknowledgements}

For this opportunity, MF and BS are grateful to Joberto V. Freitas, Claudia M.M. Rosa, Gustavo S.C. Pinho, and Tiago T. Cruz, from the Brazilian Forestry Service (SFB) and the Brazilian National Forest Inventory Project (IFN). They also thank the IFN field team, Carlos A.F. Almeida, Robson L.B. Vieira, and Tamires F. Muniz, for their support in the field, and the Instituto Chico Mendes de Conservação da Biodiversidade (ICMBio) and, in particular, Felipe C. Mendonça and Marina G. Freitas, for logistical support and cooperation on the island. JGJ and MRVB are grateful to Conselho Nacional de Desenvolvimento Científico e Tecnológico (CNPq) for their Productivity Research fellowships. We also thank W. Wayt Thomas for revising the original English version of the manuscript, and subject editor and reviewers for their contributions to the final version.

\section{Authors' Contributions}

MF and BS conducted the forest inventory and collected specimens in the field. MF, BS, and JGJ participated in the data collection. All authors wrote and contributed to the final version of the manuscript.

\section{References}

Bachman S, Moat J, Hill A, de la Torre J, Scott B (2011) Supporting Red List threat assessments with GeoCAT: geospatial conservation assessment tool. ZooKeys 150: 117-126. https://doi.org/ 10.3897/zookeys.150.2109

Barbosa MRV (2019) Chiococca. Flora do Brasil 2020 em construção, Jardim Botânico do Rio de Janeiro. http://floradobrasil.jbrj. gov.br/reflora/floradobrasil/FB13855. Accessed on: 2019-6-24.

Batistella M (1996) Espécies vegetais dominantes do arquipélago de Fernando de Noronha: grupos ecológicos e repartição espacial. Acta Botanica Brasilica 10 (2): 223-235. https://doi.org/10.1590/ S0102-33061996000200003

Browne P (1756) The civil and natural history of Jamaica. Printed for the author, London, 164-165. https://doi.org/10.5962/bhl.title.1 0826

Candolle AP (1830) Prodromus systematis naturalis regni vegetabilis. Pars quarta. Treuttel \& Würtz, Paris, 683 pp. https://doi.org/ 10.5962/bhl.title. 286

Castro JWA (2010) Geologia Ambiental das ilhas Oceânicas de Trindade e Fernando de Noronha, Brasil. Journal of Integrated Coastal Zone Management 10 (3): 33-53. https://doi.org/10.5894/rgci170

Darwin C (1839) Journal of researches into the geology and natural history of the various countries visited by H.M.S. Beagle under the command of Captain Fitzroy R.N. from 1832 to 1836 . Henry Colburn, London, 519 pp.

Davis AP, Govaerts R, Bridson DM, Ruhsam M, Moat J, Brummitt NA (2009) A global assessment of distribution, diversity, endemism and taxonomic effort in the Rubiaceae. Annals of the Missouri Botanical Garden 96 (1): 68-78. https://doi.org/10.3417/2006205

Delprete PG (2004) Chiococca plowmanii, a new species endemic to the coastal vegetation of northeastern Brazil, and a realignment of Chiococca nitida (Rubiaceae). Revista de Biologia Neotropical 1 (1-2): 4-10.

Delprete PG, Jardim JG (2012). Systematics, taxonomy and floristics of Brazilian Rubiaceae: an overview about the current status and future challenges. Rodriguésia 63 (1): 101-128. https:// doi.org/10.1590/S2175-78602012000100009

Embrapa-Monitoramento por satélite (2003) Banco de dados climáticos do Brasil. http://www.bdclima.cnpm.embrapa.br. Accessed on: 2019-04-30.

Flora do Brasil (2020) Flora do Brasil 2020 em construção. Rubiaceae. Jardim Botânico do Rio de Janeiro, Rio de Janeiro. http://floradobrasil.jbrj.gov.br/. Accessed on: 2020-03-01.

Freitas AMM (2007) A Flora fanerogâmica atual do Arquipélago de Fernando de Noronha - Brasil. Doctoral thesis, Universidade Estadual de Feira de Santana, Feira de Santana, 297 pp.

Funatura (1990) Plano de manejo do Parque Nacional Marinho de Fernando de Noronha. Instituto Brasileiro do Meio Ambiente e dos Recursos Renováveis/Fundação Pró-Natureza, Brasília, 199 pp.

IBGE (2012) Manual técnico da vegetação brasileira. Instituto Brasileiro de Geografia e Estatística, Rio de Janeiro, 271 pp.

INCT-Herbário Virtual da Flora e dos Fungos (2020). http://inct. splink.org.br. Accessed on: 2020-03-01.

IUCN (2012) IUCN Red List categories and criteria: Version 3.1 (Second edition). Gland, Switzerland and Cambridge, UK, iv + 32pp.

IUCN Standards and Petitions Subcommittee (2019) Guidelines for using the IUCN Red List categories and criteria. Version 14. Prepared by the Standards and Petitions Committee, Gland, Switzerland and Cambridge, UK, 113 pp. http://www.iucnredlist.org/ documents/RedListGuidelines.pdf. Accessed on: 2020-06-05.

Jardim JG, Taylor CM, Barbosa MR, Pessoa MCR (2015) Taxonomic notes on Chiococca and Salzmannia (Rubiaceae, Chiococceae) in northeastern Brazil, with a new combination and a new species. Phytotaxa 202 (1): 15-25. https://doi.org/10.11646/ phytotaxa.202.1.2

Lorence DH, Van Devender TR, Ferguson GM (2018) Chiococca 
grandiflora (Rubiaceae), a new species from northern Mexico. PhytoKeys 98: 73-83. https://doi.org/10.3897/phytokeys.98.25170

Machado MS, Brancalion PHS, Potascheff CM, Santos JB, Nave AG, Rodrigues RR, Gandolfi S (2013) Fenologia da frutifcação de espécies vegetais nativas e a restauração florestal no arquipélago de Fernando de Noronha, PE, Brasil. Hoehnea 40 (3): 473-483. https://doi.org/10.1590/S2236-89062013000300007

Natural History Museum (2020). Data portal query on 1 resource. 21:47:58.773096 PID. Natural History Museum, London, UK. https://doi.org/10.5519/qd.qocvolgk. Accessed on: 2020-07-09

Paudyal SK, Delprete PG, Neupane S, Motley TJ (2018) Molecular phylogenetic analysis and generic delimitations in tribe Chiococceae (Cinchonoideae, Rubiaceae). Botanical Journal of the Linnean Society 187 (3): 365-396. https://doi.org/10.1093/botlinnean/ boy029

Reflora (2020). Reflora - herbário virtual. http://floradobrasil.jbrj.gov. br/reflora/herbarioVirtual/ Acessed on: 2020-6-25

Ridley HN (1890) Notes on the botany of Fernando Noronha. The Journal of the Linnean Society, Botany 27: 1-86.

Silva Júnior MC, Felfilli JM, Proença CEB, Brasileiro ACM, Melo Filho B, Silva PEN, Costa KL (1987) Fitossociologia da mata do morro da Quixaba no território de Fernando de Noronha. Acta
Botanica Brasilica 1 (2, Supl. 1): 257-262. https://doi.org/10.1590/ S0102-33061987000300024

Schindelin J, Arganda-Carreras I, Frise E, Kaynig V, Longair M, Pietzsch T, Preibisch S, Rueden C, Saalfeld S, Schmid B, Tinevez J, White DJ, Hartenstein V, Eliceiri K, Tomancak P, Cardona A (2012) Fiji: an open-source platform for biological-image analysis. Nature Methods 9(7): 676-682. https://doi.org/10.1038/ nmeth.2019

Teixeira W, Cordani UG, Menor EA, Teixeira MG, Linsker R (2003) Arquipélago de Fernando de Noronha, o paraíso do vulcão. Terra Virgem, São Paulo, 168 pp.

Thiers B (2019) Index herbariorum: a global directory of public herbaria and associated staff [continuously updated]. http:// sweetgum.nybg.org/science/ih/. Accessed on: 2019-04-25.

Zappi D, Nunes TS (2000) Notes on the Rubiaceae of northeastern Brazil. I. Erithalis, Psychotria and Rudgea. Kew Bulletin 55: 655-668. https://doi.org/10.2307/4118782

Zappi D, Jardim J, Souza EB, Di Maio FR, Barbosa MR, Valente ASM, Santos Filho LAF, Monteiro NP (2013) Rubiaceae. In: Martinelli G, Moraes MA (Eds) Livro Vermelho da flora do Brasil. Andrea Jakobsson, Instituto de Pesquisas Jardim Botânico do Rio de Janeiro, Rio de Janeiro, 922-941. 